\title{
SINERGITAS TANGGUNGJAWAB PENDIDIKAN PADA TRI PUSAT PENDIDIKAN \\ DALAM MENANGGULANGI KENAKALAN REMAJA DI ERA GLOBALISASI
}

\author{
Zaenuri \\ STIT Ad-Dakwah Lebak Banten \\ Email: zaenurisatu@gmail.com
}

\begin{abstract}
Abstrack
The responsibility of education cannot be carried out unilaterally, it requires the cooperation of three components which Ki Hajar Dewantara calls the tricenter of education: family, educational institutions, and society. All three are a unified whole and complement each other. The involvement and role of parents and the community in guarding children's education in the era of globalization is very urgent.

This journal aims to discuss the importance of the Three Education Centers as a solution to overcome juvenile delinquency which is increasing in this era of globalization. The writing of this journal uses library research methods, or often also called library research, collecting data from various literatures.

The three educational centers both play an important role in the success of education, which basically all are interrelated and mutually cooperate with each other. The three of them must indirectly carry out close guidance in the educational process. The three links can be seen from: Parents carry out their obligations to educate children in the family, educational institutions facilitate teaching various knowledge and skills with full support from students' parents, and the community is expected to be a facilitator for students to be able to actualize their knowledge and skills.
\end{abstract}

Keywords: Responsibility, Tricenter of Education, Juvenile delinquency, Puberty.

\begin{abstract}
Abstrak
Tanggungjawab pendidikan tidak bisa dilakukan secara sepihak, dibutuhkan kerjasama tiga komponen yang oleh Ki Hajar Dewantara disebut sebagai 'tripusat pendidikan': keluarga, lembaga pendidikan, dan masyarakat. Ketiganya merupakan satu kesatuan yang utuh dan saling melengkapi satu sama lain. Keterlibatan dan peran orang tua serta masyarakat dalam mengawal pendidikan anak pada zaman globalisasi merupakan hal yang sangat urgen.

Jurnal ini bertujuan untuk membahas pentingnya Tri Pusat Pendidikan sebagai solusi untuk mengatasi kenakalan remaja yang semakin meningkat di zaman globalisasi ini. Penulisan jurnal ini menggunakan metode riset kepustakaan (library research), atau sering juga disebut studi pustaka atau penelitian kepustakaan, menghimpun data dari berbagai literatur.

Tri pusat pendidikan sama-sama memegang peran penting dalam keberhasilan pendidikan, yang pada dasarnya semua saling berkaitan dan saling kerjasama satu sama lain. Ketiganya secara tidak langsung harus mengadakan pembinaan yang erat dalam proses pendidikan. Kaitan ketiganya dapat dilihat dari: Orang tua melaksanakan kewajibannya mendidik anak dalam keluarga, lembaga pendidikan memfasilitasi mengajarkan bebagai ilmu pengetahuan dan keterampilan dengan
\end{abstract}


dukungan penuh dari orang tua peserta didik, dan Masyarakat diharapkan menjadi fasilitator bagi peserta didik untuk dapat mengaktualisasikan ilmu pengetahuan dan keterampilannya.

Kata kunci: Tanggungjawab, Tripusat Pendidikan, Kenakalan remaja, Pubertas.

\section{Pendahuluan}

Dewasa ini masyarakat semakin peka, sadar dan terbuka akan pentingnya pendidikan. Hal tersebut dapat dipahami, karena pendidikan memegang peranan penting bagi kehidupan dan masa depan umat manusia. Melalui pendidikan, manusia akan dapat membedakan tindakan yang baik dan yang buruk. Khusunya dikalangan remaja, pendidikan menjadi kunci masa depan mereka. Dengan pendidikan juga, peserta didik yang belajar dengan benar dan baik dapat membentuk pribadi yang baik pula. Pendidikan merupakan jendela dunia, dikarenakan dengan adanya pendidikan, kita bisa tahu apa saja yang belum kita ketahui. Namun, jika para pelajar tidak melaksanakan kegiatan belajar dengan serius dan kontinyu, moral mereka akan terancam dari pengaruh-pengaruh yang tidak diinginkan.

Pada zaman globalisasi ini Indonesia sedang dihadapkan pada persoalan dekadensi moral yang sangat serius, tentunya ini harus menjadi perhatian khusus dunia pendidikan. Pergeseran orientasi kepribadian yang mengarah pada berbagai perilaku amoral sudah demikian jelas dan tampak terjadi di tengah-tengah kehidupan bermasyarakat. Rasa malu, berdosa dan bersalah dari perbuatan buruk serta pelanggaran terhadap norma-norma, baik norma agama, norma hukum, dan norma susila tidak lagi menjadi tuntutan dalam menciptakan kehidupan yang bertanggungjawab dalam memelihara nilai-nilai kemanusiaan. Tantangan tersebut merupakan tugas berat yang harus diselesaikan terutama bagi dunia pendidikan agar ujian berat ke depan dapat dilalui dan dipersiapkan oleh seluruh generasi bangsa Indonesia.

Berbagai persoalan pelangaran moral di atas terutama dilakukan kalangan remaja. Hal demikian tentu menimbulkan kegelisahan-kegelisahan dalam masyarakat. Tidak sedikit tudingan-tudingan yang diarahkan pada dunia pendidikan, banyak pihak seakan menuduhnya tidak becus mendidik anak bangsa. Tuduhan ini pada akhirnya tertuju kepada pendidik yang dianggap lalai dan tidak profesional dalam menjaga moralitas bangsa. Para pendidik tiba-tiba menjadi perhatian saat terjadi kebobrokan moral, ketertinggalan ilmu, teknologi, dan peradaban. Pribadi tenaga pendidik kemudian dikupas tuntas, mulai dari penguasaan ilmu, metodologi, komunikasi, hingga moralitasnya.

Tuduhan yang langsung diarahkan pada dunia pendidikan (lembaga pendidikan), khususnya guru, kemudian mengadilinya sedemikian rupa merupakan tindakan dan sikap yang tidak bijak, karena mendidik itu pada dasarnya adalah tugas orang tua dengan melibatkan sekolah dan masyarakat. Tugas mendidik anak manusia pada dasarnya berada di pundak orang tua, namun karena keterbatasan dalam berbagai hal dan lainnya tugas ini kemudian diamanatkan kepada pendidik di madrasah, masjid, rumah-rumah ibadah, dan lembaga pendidikan lainnya. Sekolah dan masyarakat memiliki kewajiban untuk mendukung pendidikan bagi setiap generasi baru yang nantinya akan menjadi bagian dari masyarakat (Moh. Roqib, 2009:35). 
Pendidikan adalah tugas dan tanggungjawab bersama yang dilaksanakan secara sadar baik dari pihak pendidik maupun pihak terdidik. Kesadaran dalam melaksanakan pendidikan adalah dimaksudkan untuk mencapai kedewasaan dan kematangan berfikir yang dapat diusahakan melalui beberapa proses pendidikan, yaitu proses pendidikan formal, informal, dan nonformal, atau disebut juga tri pusat pendidikan. Sedangkan Menurut Zakiyah Daradjat, beberapa faktor yang menyebabkan terjadinya kenakalan siswa di antaranya adalah:

a. Kurangnya pendidikan agama.

b. Kurangnya perhatian orang tua terhadap dunia pendidikan.

c. Kurang teraturnya pengisian waktu.

d. Tidak stabilnya keadaan sosial, politik, dan ekonomi.

e. Banyaknya film-film dan buku-buku bacaan yang tidak baik.

f. Merosotnya moral dan mental orang dewasa.

g. Pendidikan dalam sekolah yang kurang baik.

h. Kurangnya perhatian masyarakat dalam pendidikan anak-anak (Zakiyah Daradjat, 1990:113).

Dari pendapat inilah dapat diketahui, bahwa secara garis besarnya faktor utama penyebab terjadinya kenakalan remaja bersumber dari dimana anak menjalani pendidikan, terutama orang tua sebagai pendidik utama dan pertama dalam kehidupan anak. Dengan demikian dalam rangka mengantisipasi upaya kenakalan remaja, tentunya dituntut pula peran serta semua 'pendidik', baik dalam lingkungan keluarga, sekolah maupun masyarakat, agar dapat menjalin kerjasama, dalam sistem pendidikan yang ditanamkan.

Membina remaja dengan pengetahuan agama atau praktek keagamaan sejak dini, serta menerapkan perhatian sepenuhnya di saat masih kecil, sehingga ketika memasuki tahap kementalan remaja, jiwanya sudah tak mudah lagi tergoncang oleh keadaan di sekitarnya. Hal ini seperti yang dikemukakan oleh zakiyah daradjat, "salah satu upaya untuk menanggulangi kenakalan siswa, yakni perlu adanya perhatian atau pembina tersendiri secara dini. Oleh karena itu pendidikan anak sudah seharusnya dimulai sejak awal pertumbuhannya" (Zakiyah Daradjat, 1990:85).

Secara mendasar boleh dikatakan bahwa penyebab terjadinya kenakalan pada usia remaja bersumber dari orang tua sebagai pendidik, juga lingkungan luar yang ada di sekitarnya, demikian pula terhadap upaya penanggulangannya, juga kembali pada orang tua itu sendiri dan para pendidik lainnya.

Oleh karena itu, dengan fakta-fakta yang ada, kita akan semakin menyadari untuk mengembalikan ruh pendidikan menuju kebermaknaan, menghasilkan insan berkarakter, taqwa, mandiri, dan cendekia, bersumber pada kearifan lokal dan berwawasan global. Untuk itulah perlunya mensinerginakan tripusat pendidikan yang terdiri dari keluarga, sekolah dan masyarakat, yang tentunya dari sanalah siswa akan mengahadapi hidup, kehidupan dan penghidupan pada masa mendatang.

Dalam sebuah hadis disebutkan,

Dari Abu Hurairah RA bahwa Rasulullah SAW telah bersabda: "Tidaklah anak yang dilahirkan itu, kecuali telah membawa fitrah beragama (perasaan percaya kepada Allah), maka kedua orang tuanyalah yang menjadikan dia Yahudi, Nasrani dan Majusi. (H.R. Bukhari) (Zainuddin Hamidy, dkk, 1992:89). 
Hadis di atas menunjukkan bahwa setiap anak Adam lahir sebagai manusia tauhid atau fitrah. Namun dalam perkembangan pribadi anak tersebut selanjutnya akan terbentuk melalui pengaruh dari lingkungan sekitarnya, dalam dunia pendidikan hal ini sejalan dengan teori konvergensi yang dikemukakan oleh William Stern, bahwa perkembangan anak akan dipengaruhi oleh faktor bakat (bawaan) dan faktor lingkungan.

Menurut Sartain, (Ahli Psikologi Amerika), yang dimaksud dengan lingkungan (environment) meliputi kondisi dan alam dunia ini yang dengan caracara tertentu mempengaruhi tingkah laku kita, pertumbuhan, perkembangan atau life process (Ngalim Purwanto, 1994):59).

Dengan demikian, potensi fitrah tersebut pada perkembangan selanjutnya akan berkembang sesuai dengan pendidikan yang diterimanya, dan sesuai pula dengan pengaruh dari lingkungannya. Dengan kata lain, lingkungan pendidikan dapat berfungsi untuk memperkuat fitrah yang telah ada dan juga dapat berfungsi untuk melemahkan fitrah tersebut. Maka agar anak tetap beragama benar sesuai dengan fitrahnya, dan untuk memperkuat fitrah yang telah ada tersebut, maka proses pendidikan yang harus dilakukan oleh tripusat Pendidikan harus dengan benar pula, terutama dalam menanamkan pendidikan akhlaq dan keagamaan.

Karena pada dasarnya pengertian pendidikan agama tidak dapat dipisahkan dangan pengertian pendidikan pada umumnya, sebab pendidikan agama merupakan bagian integral dari pendidikan secara umum. Dalam UUSPN No. 20 tahun 2003 dijelaskan bahwa:

"Pendidikan adalah usaha sadar dan terencana untuk mewujudkan suasana belajar dan proses pembelajaran agar peserta didik secara aktif mengembangkan potensi dirinya untuk memiliki kekuatan spiritual keagamaan, pengendalian diri, kepribadian, kecerdasan, akhlak mulia, serta keterampilan yang diperlukan dirinya, masyarakat, bangsa dan negara”. (Undang-undang Sistem Pendidikan Nasional No. 20 Thn 2003. Bab I, Pasal 1, 2010:2)

Menurut Muhaimin Pengertian pendidikan lebih diperluas cakupannya sebagai aktivitas dan fenomena. Pendidikan sebagai aktivitas berarti upaya secara sadar yang dirancang untuk membantu seseorang atau sekelompok orang dalam mengembangkan pandangan hidup, sikap hidup, dan keterampilan hidup, baik yang bersifat manual (petunjuk praktis) maupun mental dan sosial. Sedangkan pendidikan sebagai fenomena adalah peristiwa perjumpaan antara dua orang atau lebih yang dampaknya ialah berkembangnya suatu pandangan hidup, sikap hidup, atau keterampilan hidup pada salah satu atau beberapa pihak (Muhaimin, 2008:37).

Sebagaimana juga yang tercantum dalam Undang-undang Sistem Pendidikan Nasional pasal 3 UU No.20 Tahun 2003 tentang Tujuan Pendidikan Nasional yang menyatakan bahwa:

"Pendidikan nasional berfungsi mengembangkan kemampuan dan membentuk watak serta peradaban bangsa yang bermartabat dalam rangka mencerdaskan kehidupan bangsa, bertujuan untuk berkembangnya potensi peserta didik agar menjadi manusia yang beriman dan bertakwa kepada Tuhan Yang Maha Esa, berakhlak mulia, sehat, berilmu, cakap, kreatif, mandiri, dan 
menjadi warga negara yang demokratis serta bertanggungjawab." (Undangundang Sistem Pendidikan Nasional No. 20 Thn 2003. Bab II, Pasal 3, 2010:6).

\section{Tinjauan Pustaka}

a. Kenakalan Remaja (Juvenile Delinquency) di Era Globalisasi

Secara etimologis kenakalan remaja berasal dari bahasa Latin yang disebut dengan 'Juvenile Deliquency'. Dimana kata Juvenile artinya anak-anak, anak muda, ciri karakteristik pada masa muda, sifat-sifat khas pada periode remaja. Sedangkan kata Deliquency yang berarti terabaikan, mengabaikan; yang kemudian diperluas artinya menjadi jahat, 'a-sosial', kriminal, pelanggar aturan. Juvenile Deliquency adalah perilaku jahat/dursila, atau kejahatan/kenakalan anakanak muda; merupakan gejala sakit (patologis) secara sosial pada anak-anak dan remaja yang disebabkan oleh satu bentuk pengabaian sosial, sehingga mereka itu mengembangkan bentuk tingkah laku yang menyimpang. Pada umumnya anak remaja ini mempunyai kebiasaan yang aneh dan ciri khas tertentu, seperti cara berpakaian yang mencolok, mengeluarkan perkataan-perkataan yang buruk dan kasar, kemudian para remaja ini juga memiliki tingkah laku yang selalu mengikuti trend remaja pada saat ini (Kartini Kartono, 2014:6-8).

Kenakalan remaja atau dikenal juga dengan istilah "juvenile delinquency" ialah suatu perbuatan itu disebut delinquent apabila perbuatan-perbuatan tersebut bertentangan dengan norma-norma yang ada dalam masyarakat dimana ia hidup, suatu perbuatan yang anti sosial dimana di dalamnya terkandung unsur-unsur anti normatif (Sudarsono, 2005:5).

Kenakalan yang terjadi pada masyarakat sangat berkaitan atau identik dengan para remaja, oleh karena itu perlu kita ketahui jenjang dimana para remaja banyak melakukan aksi kenakalan yang dapat meresahkan lingkungan dimana remaja berada dan tinggal. Dalam kehidupan para remaja sering kali diselingi halhal yang negatif dalam rangka penyesuaian dengan lingkungan sekitar baik lingkungan dengan teman-temannya di sekolah maupun lingkungan pada saat dia di rumah. Hal-hal tersebut dapat berbentuk positif hingga negatif yang sering kita sebut dengan 'kenakalan remaja'. Kenakalan remaja itu sendiri merupakan perbuatan pelanggaran norma-norma baik norma hukum maupun norma sosial (Agoes Dariyo, 2004:13-14.).

Dadang Hawari mengatakan bahwa suatu perbuatan dikatakan nakal apabila melanggar atau menyimpang dari norma agama, sekolah dan masyarakat. Standar moralitas menurut ajaran agama sudah jelas dan standar tersebut kemudian diberlakukan di lingkungan sekolah dan masyarakat, meskipun kadang kala masyarakat setempat mempunyai standar nilai yang mengacu pada adat istiadat setempat (H. Ridjaluddin, 2008:6).

Menurut Sarlito Wirawan Sarwono, ,juvenile delinquency dibagi menjadi 4 macam yaitu:

1) Kenakalan yang menimbulkan korban fisik pada orang lain seperti perkelahian, pemerkosaan, pembunuhan dan sebagainya.

2) Kenakalan yang merugikan materi pada orang lain seperti pencurian, pencopetan, pemerasan.

3) Kenakalan sosial yang tidak menimbulkan korban pada orang lain seperti pelacuran, perzinaan.

4) Kenakalan yang bersifat melawan status seperti membolos sekolah, pergi dari rumah (Sarlito Wirawan Sarwono, 1994:200). 
Dari beberapa pengertian diatas dapat ditarik kesimpulan bahwa kenakalan remaja (juvenile delinquency) adalah segala perbuatan yang dilakukan oleh anakanak remaja dengan melanggar setiap norma-norma yang berlaku dalam suatu masyarakat dan banyak merujuk pada masalah sosio psikologis, kadang pula digolongkan penyakit sosial sehingga dapat menimbulkan keresahan bagi masyarakat.

Istilah remaja (adolescence) berasal dari kata latin adolescere (kata bendanya, adolescentia yang berarti remaja) yang berarti "tumbuh" atau tumbuh menjadi dewasa, istilah adolescence, seperti yang dipergunakan untuk saat ini, mempunyai arti yang lebih luas yang mencakup kematangan mental, emosional, sosoial, dan fisik ( ${ }^{1}$ Elizabeth B Hurlock, 2005:206.). Remaja sebenarnya tidak mempunyai tempat yang jelas karena tidak termasuk golongan anak tetapi tidak juga golongan dewasa atau tua. Adapun pengertian remaja menurut beberapa ahli ialah sebagai berikut:

1) Menurut Sri Rumini dan Siti Sundari, masa remaja adalah peralihan dari masa anak dengan masa dewasa yang mengalami perkembangan semua aspek/ fungsi untuk memasuki masa dewasa. Masa dewasa berlangsung antara umur 12 tahunsampai dengan 21 tahun bagi wanita dan 13 tahun sampai dengan 22 tahun bagi pria (Sri Rumini dan Siti Sundari, 2004:53).

2) Menurut Dzakiah Darajat, masa remaja adalah masa peralihan anatara masa kanak-kanak dan dewasa. Dalam masa ini anakanak mengalami masa pertumbuhan dan perkembangan fisiknya maupun perkembangan psikisnya. Mereka bukanlah anak-anak baik bentuk badan ataupun cara berpikir atau bertindak, tetapi bukan pula orang dewasa yang telah matang (Zakiyah Darajat, 2010:23).

3) Santrock mengartikan adolescence sebagai masa perkembangan transisi antara masa anak dan masa dewasa yang mencakup perubahan biologis, kognitif, dan social-emosional (Jhon W. Santrock, 2002:26).

Batasan usia remaja yang umum digunakan oleh para ahli tersebut adalah antara 12 hingga 21 tahun. Rentang waktu usia remaja yang biasanya dibedakan atas tiga, yaitu 12 - 15 tahun (masa remaja awal), 15 - 18 tahun (masa remaja pertengahan), dan $18-21$ tahun (masa remaja akhir).

Dari beberapa pengertian para ahli tentang definisi remaja diatas tersebut menggambarkan bahwa masa remaja adalah masa peralihan dari masa kanakkanak dengan masa dewasa dengan rentang usia antara 12 - 22 tahun, dimana pada masa tersebut terjadi proses pematangan baik itu pematangan fisik maupun psikologis. berikut:

Adapun Beberapa bentuk juvenile delinquency di antaranya sebagai

1) Kebut-kebutan di jalanan yang mengganggu keamanan lalu lintas dan membahayakan jiwa sendiri serta orang lain.

2) Perilaku ugal-ugalan, berandalan, urakan yang mengacaukan ketentraman milieu sekitar, tingkah ini bersumber pada kelebihan energi dan dorongan primitif yang tidak terkendali serta kesukaan menteror lingkungan.

3) Perkelahian antar geng, antar kelompok, antar sekolah, antar suku (tawuran), sehingga kadang-kadang membawa korban jiwa. 
4) Membolos sekolah lalu bergelandangan di pinggir jalan atau bersembunyi di tempat-tempat terpencil sambil melakukan eksperimen bermacam-macam kedurjanaan dan tindak asusila.

5) Kriminalitas anak, remaja dan adolerens antara lain berupa perbuatan mengancam, intimidasi, memeras, maling, mencuri, mencopet, merampas, menjambret, menyerang, menggarong, melakukan pembunuhan dengan jalan menyembelih korbannya, mencekik, meracun, tindak kekerasan dan pelanggaran lainnya.

6) Berpesta pora, sambil mabuk-mabukan, melakukan hubungan seks bebas, atau orgi (mabuk-mabukan hebat dan menimbulkan keadaan yang kacau balau) yang mengganggu lingkungan.

7) Perkosaan, agresivitas seksual dan pembunuhan dengan motif seksual atau didorong oleh reaksi-reaksi kompensatoris dari perasaan interior menurut pengakuan diri, depresi hebat, rasa kesunyian, emosi balas dendam, kekacauan ditolak cintanya seorang wanita dan lain-lain.

8) Kekacauan dan ketagihan bahan narkotika (obat bius/drugs) yang erat bergandengan dengan tindak kejahatan.

9) Tindak-tindak immoral seksual secara terang-terangan tanpa tedeng aling-aling, tanpa rasa malu dengan cara yang kasar. Ada seks dan cinta bebas tanpa kendali (promiscuity) yang didorong oleh hiperseksualitas geltungsrieb (dorongan menuntut hak) dan usahausaha kompensasi lainnya yang kriminal sifatnya.

10) Homo seksualitas, erotisme anal dan oral dan gangguan seksual lainnya selain pada anak remaja disertai tindak-tindak distis.

11) Perjudian dan bentuk-bentuk lain dengan taruhan, sehingga mengakibatkan ekses kriminalitas.

12) Komersialisasi seks, pengguguran janin-janin oleh gadis delinquen.

13) Tindakan radikal dan ekstrim dengan cara kekerasan, penculikan dan pembunuhan yang dilakukan anak-anak remaja.

14) Perbuatan asosial dan anti sosial lain disebabkan oleh gangguan kejiwaan pada anak-anak remaja psikopatik, psikotik, neurotik dan menderita gangguan-gangguan jiwa lainnya.

15) Tindak kejahatan disebabkan oleh penyakit tidur (encephalitis lethargical) dan ledakan meningitis serta post-encephalitis, juga luka di kepala dengan kerusakan pada otak adakalanya membuahkan kerusakan mental sehingga orang yang bersangkutan tidak mampu melakukan kontrol diri.

16) Penyimpangan tingkah laku disebabkan oleh kerusakan pada karakter anak yang menuntut kompensasi disebabkan adanya organorgan inferior (Kartini Kartono, tt:21-23).

Dari segi hukum kenakalan remaja digolongkan dalam dua kelompok yang berkaitan dengan norma-norma hukum yaitu: a) kenakalan yang bersifat amoral dan sosial serta tidak diantar dalam undang-undang sehingga tidak dapat atau sulit digolongkan sebagai pelanggaran hukum; dan b) kenakalan yang bersifat melanggar hukum dengan penyelesaian sesuai dengan undang-undang dan hukum yang berlaku sama dengan perbuatan melanggar hukum bila dilakukan orang dewasa (Singgih D Gunarsa dan Yulia Singgih D Gunarsa, 1995:183). 
Menurut Tingkatannya, Sunarwiyati membagi kenakalan remaja ke dalam tiga tingkatan: a) kenakalan biasa, seperti suka berkelahi, suka keluyuran, membolos sekolah, pergi dari rumah tanpa pamit; b) kenakalan yang menjurus pada pelanggaran dan kejahatan seperti mengendarai mobil tanpa SIM, mengambil barang orang tua tanpa izin; dan (3) kenakalan khusus seperti penyalahgunaan narkotika, hubungan seks di luar nikah, pemerkosaan dan lainlain (Tri Andria, 2016:169.).

Tujuan pendidikan akan terwujud melalui tripusat pendidikan yaitu, formal, non formal, dan informal. Remaja sangat cocok untuk disebutkan bagi kalangan siswa di tingkat menegah ke atas (SMP/SMA) dan setingkatnya. Sebagaimana diketahui bahwa pada masa ini merupakan peralihan dari masa anak-anak ke masa dewasa. Para ahli pendidikan sependapat bahwa remaja dari usia 13 tahun sampai dengan 18 tahun cendrung nakal dikarenakan belum mengetahui jati dirinya sendiri. Masih perlu mencari jati dirinya. Seseorang remaja tidak dapat dikatakan dewasa, mereka sedang mencari pola kehidupan yang paling sesuai baginya dan inipun sering dilakukan melalui metode mencoba walaupun banyak kesalahan ( ${ }^{1}$ Departemen Pendidikan dan Kebudayaan, 1999:635).

Dari berbagai pendapat di atas dapat disimpulkan bahwa remaja adalah seorang individu yang belum dewasa dan masih perlu bimbingan dan pendidikan dari orang tua.

Tidak dapat disangkal, usia remaja adalah bagian dari pada umur manusia yang amat rentan terhadap berbagai persoalan hidup. Pada usia ini, berbagai gejolak bisa timbul dalam kehidupan remaja, termasuk mudah menerima dan mengikuti budaya dan pola hidup orang-orang Barat yang tidak sesuai dengan anjuran Islam. Hal ini sesuai dengan pendapat para psikolog yang mengatakan bahwa "pada masa remaja sesungguhnya sedang menghadapi masa terbentuknya konsep diri, intelegensi, peran sosial dan seksual, namun terpenting di antaranya adalah terbentuknya sistem moral religi" (Departemen Pendidikan dan Kebudayaan, 1999:635).

Anak remaja yang melakukan perbuatan-perbuatan bermoral dan bernilai akhlakul-karimah merupakan hasil dari pengalaman dan pengetahuan mereka dari contoh-contoh dan pelajaran yang diberikan oleh kedua orang tua di rumah, para pendidik di sekolah dan pemuka masyarakat. Terciptanya suasana yang serba positif dalam lingkungan kehidupan anak remaja dapat berakibat baik terhadap perkembangan mentalnya, demikian pula sebaliknya, jika lingkungan hidup anak remaja negatif, maka hal itu dapat berakibat buruk terhadap perkembangan mentalnya (Departemen Pendidikan dan Kebudayaan, 1999:635).

Di era globalisasi seperti sekarang ini, bangsa Indonesia dihadapkan pada berbagai tantangan yang berskala global. Globalisasi tidak hanya menyebabkan terjadinya transformasi peradaban dunia melalui proses modernisasi, industrialisasi, dan revolusi informasi, tapi juga menimbulkan perubahan dalam struktur kehidupan dalam berbagai bidang, baik dibidang sosial, budaya, ekonomi, politik maupun pendidikan. Globalisasi selain menghadirkan peluang "positif" untuk hidup mewah, nyaman, murah, indah, dan maju juga dapat menghadirkan peluang "negatif" yaitu menimbulkan keresahan, penyesalan, dan penderitaan. Globalisasi bekerja selama 24 jam dengan menawarkan banyak pilihan dan kebebasan yang bersifat pribadi. Tugas pendidikan adalah membawa generasi ini merengkuh sedemikian agar manusia tidak tercabut dari kemampuannya dalam 
menghadapi kontradiksi alam yang selalu mengalami perubahan. Globalisasi sebagai proses terkait dengan globalution, yaitu paduan dari globalization dan evolution. Dalam hal ini, globalisasi adalah hasil perubahan (evolusi) dari hubungan masyarakat yang membawa kesadaran baru tentang hubungan atau interaksi antarumat manusia (Nurani Soyomukti, 2008:43).

Namun demikian, hanya sedikit orang yang sadar dan secara kritis memahami bahaya globalisasi yang secara sistematik mengancam kehidupan manusia. Sebab globalisasi hanya dipahami dari aspek kemajuan teknologi saja bukan dari aspek-aspek lain yang sesungguhnya mempunyai implikasi sosial luar biasa dalam kehidupan manusia (Musthafa Rembangy, 2008:33).

Muhammad Tholchah Hasan mengemukakan tantangan pendidikan terutama pendidikan Islam yang harus dihadapi di era global ini adalah kebodohan, kebobrokan moral, dan hilangnya karakter muslim (Bashori Muchsin dan Abdul Wahid, 2009:60). Secara lebih terperinci beberapa tantangan yang ditimbulkan oleh globalisasi informasi dan komunikasi adalah :

1) Keberadaan publikasi informasi merupakan sarana efektif penyebaran isu, sehingga dapat menimbulkan saling kecurigaan di antara umat.

2) Dalam banyak aspek keperkasaan Barat dalam dominasi dan imperalisasi informasi, yang dapat menimbulkan sukularisme, kapitalisme, pragmatisme, dan sebagainya.

3) Dari sisi pelaksanaan komunikasi informasi, ekspos persoalan seksualitas, peperangan, dan kriminal, berdampak besar pada pembentukan moral dan perubahan tingkah laku.

4) Lemahnya sumber daya Muslim sehingga di banyak hal harus mengimport produk teknologi Barat (Jurnal at-Ta'dib, V ol. 7, No. 2, Desember 2012 (Ponorogo: IAID Gontor), hlm. 272-273).

Dan inilah menurut para pakar pendidikan yang menjadi 'PR' besar bagi setiap institusi pendidikan termasuk pendidikan Islam. Dengan melihat fenomena tersebut, jelas tidak dapat dipungkiri lagi.

Adapun di antara dampak negatif globalisasi sebagai berikut:

1) Pemiskinan nilai spiritual, tindakan sosial yang tidak mempunyai implikasi materi (tidak produktif) dianggap sebagai tindakan yang tidak rasional.

2) Kejatuhan manusia dari mahluk spiritual dari mahluk spiritual menjadi mahluk material, yang menyebabkan nafsu hewaninya menjadi pemandu kehidupan manusia.

3) Peran agama digeser menjadi urusan akhirat saja, sedangkan urusan dunia menjadi urusan sains (sekularistik).

4) Tuhan hanya hadir dalam pikiran, lisan dan tulisan, tetapi tidak hadir dalam prilaku dan tindakan.

5) Gabungan ikatan primodial dengan sistem politik modern melahirkan nepotisme, birokratisme, dan otoriterisme.

6) Indvidualistik, keluarga pada umumnya kehilangan fungsinya sebagai unit terkecil pengambil keputusan. Seseorang bertanggungjawab kepada dirinya sendiri, tidak lagi bertanggungjawab pada keluarga. Ikatan moral dalam keluarga semakin lemah, dan keluarga dianggap sebagai lembaga yang teramat tradisional.

7) Terjadinya frustasi eksistensial (existential frustation) dengan ciricirinya: pertama, hasrat yang berlebihan untuk berkuasa (the will to 
power) bersenang-senang mencari kenikmatan (the will to pleasure) yang biasanya tercermin dalam prilaku yang berlebihan untuk mengumpulkan uang (the will to money), untuk bekerja (the wil of work), dan kenikmatan seksual (the will to sex). Kedua, kehampaan eksistensial berupa perasaan serba hampa, tak berarti hidupnya, dan lain-lain. Ketiga, neurosis noogenik; perasaan hidup tanpa arti, bosan, apatis, tak mempunyai tujuan, dan sebagainya.

8) Akibat globalisasi informasi; manusia akan menghadapi tantangan globalisasi nilai; apa yang diterima melalui informasi oleh sebagian orang dikumpulkan menjadi nilai yang dianggap baik terutama oleh generasi atau kelompok yang belum memegang nilai agama dan nilai sosial dan budaya dengan kuat. Pada sisi lain bisa mengalami kecemasan informasi; orang mengumpulkan informasi sebanyak mungkin, tetapi belum tentu mengelolanya dengan baik agar informasi yang tepat dalam bentuk yang sesuai dapat ditentukan dengan cepat dan dapat dimanfaatkan pada waktu yang tepat secara efisien. Pada sisi lain bisa pula terjadinya ketegangan-ketegangan: informasi di kota dan di desa, kaya dan miskin, konsumeris, dan kekurangan.

9) Sebagai akibat globalisasi itu pula, sebagian orang terutama generasi muda boleh jadi akan kehilangan kreativitas karena kenikmatan kemajuan. Sehingga apabila muncul tantangan, mereka akan mengalami keterkejutan (Haidar Daulaby, 1998:129-130).

Globalisasi merupakan suatu entitas, betapapun kecilnya, yang bilamana disampaikan oleh siapa pun, dimana pun, dan kapanpun, akan dengan cepat menyebar ke seluruh pelosok dunia. Bila entitas tadi telah menjadi lifestyle dan simbol kemodernan, ia dapat mengubah kebiasaan hidup seseorang, bahkan tidak jarang menilai ajaran agama sebagai ketinggalan zaman (Musthafa Rembangy, $\mathrm{tt}: 8)$.

Jika memperhatikan penjelasan tentang globalisasi di atas, maka semakin jelaslah kenakalan remaja yang semakin meningkat akhir-akhir ini merupakan imbas dampak negatif dari globalisasi, ini tentunya harus menjadi salah satu fokus perhatian semua pihak, tripusat pendidikan yang ditunjang oleh kebijakankebijakan pemerintah yang mendukung penuh pencegahan dan penanggulangan kenakalan remaja.

\section{Tripusat Pendidikan}

Lingkungan pendidikan menurut Ki Hadjar Dewantara dibedakan menjadi tiga, yaitu Keluarga, sekolah, dan masyarakat, yang sering pula disebut sebagai Tripusat Pendidikan. Tri pusat pendidikan merupakan wahana dimana peserta didik belajar dan mengaplikasikan hasil beajarnya. Namun sayangnya, ide yang dicetuskan oleh Ki Hadjar Dewantara pada tahun 1920 saat ini telah luntur, dan kabur. Metode asah, asih, dan asuh sekarang banyak digantikan oleh orang lain yang pada dasarnya bukan orang yang seharusnya melakukan metode ini, akibatnya timbullah ketimpangan disana sini. Saat inilah kita harus bangkit kembali menyatukan dan mensinergikan tripusat pendidikan: keluarga, sekolah, dan masyarakat untuk bertindak secara simultan serta meneguhkan kembali Ing ngarsa sung tuladha; Ing madya mangun karsa; dan Tut wuri handayani dalam pendidikan. Berikut akan sedikit diuraikan peran Tripusat Pendidikan satu persatu. 


\section{1) Lingkungan Keluarga}

Islam memandang bahwa keluarga mempunyai pengaruh yang paling dominan dalam pembentukan kepribadian anak. Hal ini disebabkan: a) tanggung jawab orang tua pada anak bukan hanya bersifat duniawi, melainkan ukhrowi dan teologis; b) orang tua disamping memberikan pengaruh yang bersifat empiris setiap hari, juga memberikan pengaruh hereditas dan genesitas, yakni bakat dan pembawaan serta hubungan darah yang melekat pada diri anak; c) Kedua anak lebih banyak tinggal atau berada di rumah dibandingkan dengan di luar rumah; dan d) orang tua atau keluarga sebagai yang lebih dahulu memberikan pengaruh, dan pengaruh yang lebih dahulu ini pengaruhnya lebih kuat dibandingkan dengan pengaruh yang datang belakangan (Abudin Nata, 2010:299).

Dengan demikian sudah selayaknya dan selazimnya keluarga (ayah dan ibu) memberikan pendidikan dan pengawasan yang cukup ketat terhadap anak dengan tetap memperhatikan psikologi perkembangan dan pertumbuhannya.

\section{2) Lingkungan Sekolah}

Lingkungan sekolah adalah kelanjutan dari lingkungan rumah tangga. Pada lingkungan sekolah ini, tugas pendidikan diserahkan kepada guru, mu'allim atau ulama. Di sekolah seorang anak mendapatkan berbagai informasi tentang ilmu pengetahuan serta ketrampilan yang diperlukan dalam kehidupannya. Jika orang tua mengajar dan mendidik di rumah, maka seorang guru mengajarkan ilmunya di sekolah atau di majelis-majelis ilmu, atau di rumah-rumah yang memungkinkan untuk menyelenggrakan pendidikan dan pengajaran (Abudin Nata, tt:300).

\section{3) Lingkungan Masyarakat}

Lingkungan masyarakat, pada hakikatnya adalah kumpulan dari keluarga yang antara satu dan lainnya terkait oleh tata nilai atau aturan baik yang tertulis maupun tidak tertulis. Masyarakat merupakan wahana interaksi sosial yang mempunyai dampak besar dalam pengembangan dan pemberdayaan potensi peserta didik yang sekaligus tempat mengimplementasikan apa yang didapatkan di keluarga dan sekolah.

Dalam masyarakat ada beberapa organisasi, lembaga, institusi, perkumpulan, asosiasi yang itu semua merupakan wadah dan peluang untuk memperoleh pengalaman empiris yang kelak akan berguna bagi kehidupannya di masa depan. Oleh karenanya seharusnya berbagai kegiatan sosial kemasyarakatan harus berorientasi pada pengembangan dan pemberdayaan potensi peserta didik untuk mengatasi permasalahan kualitas dan relevansi pendidikan yang menjadikan rendahnya daya saing lulusan (Mohammad Ali, 2009:239).

\section{Metodologi}

Penulisan jurnal ini merupakan jenis riset kepustakaan (library research), atau sering juga disebut studi pustaka atau penelitian kepustakaan, yaitu jenis penelitian yang dilakukan dengan membaca buku-buku atau majalah dan sumber data lainnya untuk menghimpun data dari berbagai literatur, baik perpustakaan maupun di tempat-tempat lain (Mahmud, 2011:31). Pengumpulan data dalam penelitian dilakukan dengan menelaah dan/atau mengekplorasi beberapa Jurnal, buku, dan dokumen-dokumen (baik yang berbentuk cetak maupun elektronik) serta sumber-sumber data dan atau informasi lainnya yang dianggap relevan dengan penelitian atau kajian. 


\section{Hasil Pembahasan}

Setiap manusia akan selalu berada dan mengalami perkembangan dalam tiga lingkungan pendidikan tersebut. Pada garis besarnya kita mengenal tiga lingkungan pendidikan. Tiga lingkungan ini disebut dengan Tripusat Pendidikan. Tripusat pendidikan adalah tiga pusat tempat kita dididik yang bertanggungjawab atas terselenggaranya pendidikan yaitu dalam keluarga, sekolah dan masyarakat. Dalam UU No 20 Tahun 2003 tentang sistem pendidikan Nasional pada pasal 13 ayat 1 disebutkan bahwa jalur pendidikan terdiri atas pendidikan formal, non formal dan informal yang dapat saling melengkapi dan memperkaya (Undangundang Nomor 20 Tahun 2003, tentang Sistem Pendidikan Nasional, Lihat Bab VI Pasal 13 Ayat 1).

Mengenai sinergitas Tri Pusat Pendidikan tertuang dalam keterangan Ki Hajar Dewantara, di antaranya:

a. Keinsyafan $\mathrm{Ki}$ Hajar Dewantara bahwa tujuan pendidikan tidak mungkin tercapai hanya melalui hanya satu jalur.

b. Ketiga pusat pendidikan tersebut harus berhubungan akrab serta harmonis.

c. Alam keluarga tetap merupakan pusat pendidikan yang terpenting dan memberikan pendidikan budi pekerti, agama, dan laku sosial.

d. Perguruan sebagai balai wiyata yang memberikan ilmu pengetahuan dan pendidikan keterampilan.

e. Alam pemuda (yang sekarang diperluas menjadi lingkungan/alam kemasyarakatan) sebagai tempat sang anak berlatih membentuk watak atau karakter dan kepribadian seseorang.

f. Dasar pemikiran Ki Hajar Dewantara ialah usaha untuk menghidupkan, menambah, dan memberikan perasaan kesosialan pada sang anak (Rulam Ahmadi, 2014:171).

Dari keterangan di atas dapat kita pahami, bahwa ketiga pusat pendidikan sama-sama memegang peran sangat penting dalam keberhasilan pendidikan, dan pada dasarnya semua saling berkaitan dan saling kerjasama satu sama lain. Ketiganya secara tidak langsung telah mengadakan pembinaan yang erat dalam praktik pendidikan. Kaitan ketiganya dapat dilihat dari :

a. Orang tua melaksanakan kewajibannya mendidik anak dalam keluarga.

b. Karena keterbatasan orangtua dalam mendidik anak di rumah, dan akhirnya proses pendidikan diserahkan pada sekolah.

c. Masyarakat akan menjadi fasilitator bagi peserta didik untuk mengaktualisasikan keterampilannya (Novan Ardy Wiyani dan Barnawi, 2012:90).

\section{Kesimpulan}

Dari uraian di atas dapat disimpulkan bahwa peran keluarga, sekolah, dan masyarakat peduli pendidikan tidak dapat dipisahkan. Ketiganya merupakan tripusat pendidikan yang harus secara sinergis dan simultan merencanakan, memantau, dan mengevaluasi pendidikan di sekolah. Bila ketiga unsur tersebut mempunyai pemahaman yang sama akan peranannya dalam pendidikan, niscaya ketiga unsur tersebut akan berjalan secara sinergi dan simultan. Dengan adanya sinergitas dari ketiga unsur tersebut dapat diharapkan pendidikan akan lebih bermakna, karena dengan kebersamaan tiga unsur tersebut setidaknya proses 
pendidikan tidak akan mengabaikan peran keluarga yang dari pendidikan keluargalah karakter siswa terbentuk, kemudian pendidikan di masyarakat akan menanamkan nilai-nilai luhur dan kearifan lokal sebagai bentuk warisan budaya akan tetap terjaga, sehingga pengembangan IPTEKS (Ilmu Pengetahuan, Teknologi dan Seni) juga tetap terkendali dengan tanpa meninggalkan nilai-nilai luhur yang tetap perlu dijaga dan dilestarikan bila peran sekolah dan masyarakat juga maksimal. Dengan sinergisme antara keluarga, sekolah, dan masyarakat, kebermaknaan pendidikan akan dapat tercapai untuk menghasilkan insan berkarakter, taqwa, mandiri, dan cendekiwan yang menguasai dan mampu mengembangkan IPTEKS dalam memenuhi tuntutan dan tantangan global.

Jelaslah bahwa kenakalan remaja sangat dipengaruhi oleh keluarga walaupun faktor lingkungan juga sangat berpengaruh. Faktor keluarga sangatlah penting karena merupakan lingkungan pertama, lingkungan primer. Apabila lingkungan keluarga tidak harmonis yaitu menglami hal-hal yang telah disebutkan di atas seperti keluarga broken home yang disebabkan perceraian, kebudayaan bisu, dan perang dingin serta kesalahan pendidikan akan berpengaruh kepada anak yang dapat menimbulkan kenakalan remaja. Bagaimanapun kenakalan remaja harus dilakukan pengendalian karena apabila berkelanjutan akan menyebabkan kerusakan pada kehidupannya pada masa yang akan datang. Selain dari pihak keluarga pengendalian kenakalan remaja juga harus dilakukan dari lingkungan remaja tersebut.

Sebagaimana dijelaskan pada awal pembahasan, bahwa pendidikan anak pada perkembangan selanjutnya juga dipengaruhi oleh lingkungan yang terdiri dari lingkungan keluarga, sekolah dan masyarakat, maka pendidikan pun merupakan tugas bersama antara sekolah, orang tua, dan masyarakat, termasuk dalam masyarakat yaitu pemerintah, yang disebut dengan Tri Pusat Pendidikan yakni tiga pusat pendidikan yang secara bertahap dan terpadu mengemban suatu tanggungjawab pendidikan bagi generasi mudanya.

\section{Saran}

Adapun beberapa saran dari penulis sebagai upaya dalam sinergitas tripusat pendidikan di antaranya:

a. Pihak sekolah sebagai lembaga pendidikan formal, khususnya kepada guru-guru agama dan umumnya guru mata pelajaran yang lain agar terus meningkatkan kualitas dirinya. Selain itu, hal yang terpenting adalah guru harus memberikan dan menjadi teladan yang baik dalam segala tingkah laku dan di setiap keadaan, karena keadaan guru itu akan selalu dijadikan cermin bagi anak didiknya.

b. Orang tua di rumah jangan sepenuhnya menyerahkan pendidikan terutama dalam penanaman budi pekerti dan pengamalan ajaran keagamaan anaknya semata-mata kepada sekolah atau lembaga pendidikan lainnya untuk mendidik mereka. Karena keluarga merupakan tempat pertama dan utama dalam menanamkan pendidikan agama kepada anak. Selain itu sesungguhnya waktu yang lebih banyak dihabiskan anak adalah waktunya bersama keluarga dibandingkan waktu yang dihabiskan di sekolah. Karena itu orang tua juga harus menjadi teladan yang baik yang tidak hanya memerintahkan anaknya untuk belajar atau mengamalkan ajaran agama tetapi ia juga harus mencerminkan apa yang diperintahkan kepada anaknya. Sebagai contoh misalnya, anak-anak di sekolah mendapatkan 
pendidikan agama dari Guru Agama, tetapi keluarganya terutama orang tuanya adalah orang yang tidak aktif menjalankan ajaran agama atau bahkan bersikap acuh tak acuh, maka keadaan seperti ini akan berpengaruh negatif terhadap pertumbuhan jiwa keagamaan anak, karena kurang mendapatkan pembinaan dari lingkungannya.

c. Para tokoh masyarakat, baik secara pribadi atau kelompok, seperti pemuka agama, tokoh pemuda, organisasi keagamaan, organisasi kepemudaan yang membina komunitas remaja dan juga pihak yang lainnya terutama pemerintah diharapkan juga dapat membantu secara aktif terselenggaranya pendidikan moral, akhlak dan keagamaan dengan berbagai upaya yang dilakukan sesuai dengan kewenangan dan tanggungjawab yang diembannya. Sehingga tujuan pendidikan yang kita harapkan bersama dapat terwujud.

\section{Daftar Pustaka}

Nata, Abudin. 2010. Ilmu Pendidikan Islam.Jakarta: Kencana Prenada Media Grup.

Dariyo, Agoes. 2004. Psikologi Perkembangan Remaja. Jakarta: Ghalia Indonesia.

Muchsin, Bashori dan Abdul Wahid. 2009. Pendidikan Islam Kontemporer. Bandung: Refika Aditama.

Departemen Pendidikan dan Kebudayaan. 1999. Kamus Besar Bahasa Indonesia. Jakarta: Balai Pustaka.

Hurlock, Elizabeth B. 2005. Psikologi Perkembangan: Suatu Pendekatan Sepanjang Rentang Kehidupan. Erlangga: Jakarta.

Ridjaluddin, H.. 2008. Psikologi Agama. Tinjauan Islam Terhadap Kenakalan Pelajar. Jakarta: LKI Nugraha.

Daulaby, Haidar. 1998. Perguruan Tinggi Islam di Era Globalisasi. Yogyakarta: Tiara Wacana.

Kartono, Kartini. 2014. Patologi Sosial 2 Kenakalan Remaja. Jakarta: Rajagrafindo Persada.

Roqib, Moh. 2009. Ilmu Pendidikan Islam: Pengembangan Pendidikan Integratif di Sekolah. Keluarga. dan Masyarakat. Yogyakarta: LKiS.

Rafiq, Moh. Tantangan dan Peluang Komunikasi Islam Pada Era Globalisasi Informasi. Dalam Syamsirin. 2012. Tinjauan Filosofis Tantangan Pendidikan Islam pada Era Globalisasi. Jurnal at-Ta'dib. Vol. 7. No. 2. Desember 2012 (Ponorogo: IAID Gontor).

Ali, Mohammad. 2009. Pendidikan untuk Pembangunan Nasional: Menuju Bangsa Indonesia yang Mandiri dan Berdaya Saing Tinggi. Bandung: Imperial Bhakti Utama.

Muhaimin. 2008. Paradigma Pendidikan Islam: Upaya Mengefektifkan Pendidikan Agama Islam di Sekolah. Bandung: Remaja Rosdakarya.

Rembangy, Musthafa. 2008. Pendidikan Transformatif. Yogyakarta: Teras.

Purwanto, Ngalim. 1994. Ilmu Pendidikan Teoritis dan Praktis. Bandung: Remaja Rosdakarya.

Wiyani, Novan Ardy dan Barnawi. 2012. Ilmu Pendidikan Islam. Yogyakarta: ArRuzz Media.

Soyomukti, Nurani. 2008. Pendidikan Berperspektif Globalisasi. Yogyakarta: ArRuzz Media. 
Ahmadi, Rulam. 2014. Pengantar Pendidikan: Asas dan Filsafat Pendidikan. Yogyakarta: Ar-Rum Media.

Santrock, Jhon W. 2002. Life-Span Development: Perkembangan Masa Hidup. Jakarta: Erlangga.

Sarwono, Sarlito Wirawan. 1994. Psikologi Remaja. Jakarta: Rajagrafindo Persada.

Gunarsa, Singgih D., dan Yulia Singgih D. Gunarsa. 1995. Psikologi Praktis: Anak, Remaja dan Keluarga. Jakarta: BPK Gunung Mulia.

Rumini, Sri dan Siti Sundari. 2004. Perkembangan Anak dan Remaja. Rineka Cipta: Jakarta.

Sudarsono. 2005. Etika Tentang Kenakalan Remaja. Jakarta: Rineka Cipta.

Andria, Tri. 2016. Peran Bimbingan Keagamaan dalam Penanggulangan Kenakalan Remaja. Jurnal Bimas Islam Vol.9. No.I 2016. Jakarta: Ditjen Bimas Islam Kementerian Agama Republik Indonesia.

Tim Fokus Media. 2010. Undang-undang Sistem Pendidikan Nasional Nomor 20 Tahun 2003. Bandung: Fokusmedia.

Hamidy, Zainuddin, dkk. Terjemah Shahih Bukhari Jilid II. Jakarta: Wijaya.

Daradjat, Zakiyah. 1990. Kesehatan Mental. Jakarta: Haji Masagung. 1990. Ilmu Jiwa Agama. Jakarta: Bulan Bintang.

Bintang. 1985. Membina Nilai-nilai di Indonesia. Jakarta: Bulan 